Pamiętnik Literacki 2012, 2, s. 115-139
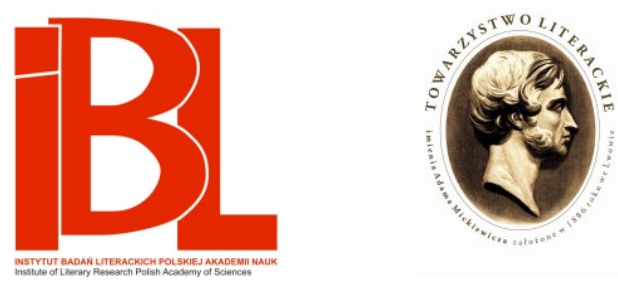

Doświadczenie jako próba dzieła - próba siebie

Irena Górska 


\title{
DOŚWIADCZENIE JAKO PRÓBA DZIEŁA - PRÓBA SIEBIE
}

\author{
Jeśli prawdą jest, że artysta spala się w swej twórczości, to \\ jego dzieło jest popiołem... ${ }^{1}$
}

Nie sposób mówić o sztuce, estetyce bez odwołania się do ludzkiego doświadczenia. W kontekście twórczości Tadeusza Kantora warto przywołać przede wszystkim kategorię doświadczenia rozumianego jako próba. Twórczość tego artysty jawi się bowiem jako nieustanne próbowanie, doświadczanie siebie samego, swego dzieła i siebie w dziele. To ujęcie odsyła też do doświadczenia, które za Arnoldem Berleantem można określić jako percepcyjne ${ }^{2}$, które miałoby angażować wszystkie zmysły, zarówno mentalne, jak i cielesne. Wydaje się to zasadne, gdyż twórca Teatru Śmierci sam wskazuje dwa zasadnicze kierunki myślenia o sobie samym, o własnym dziele i jego źródłach. Jeden odsyła ku umysłowi, psychice, świadomości, drugi ku ciału.

W swojej pracy Kantor jawi się jako performer, który nieustannie eksperymentuje na samym sobie i z samym sobą, który wystawia na pokaz siebie w sensie fizycznym i psychicznym, który wreszcie niczego nie gra, nie udaje, lecz prezentuje tylko siebie samego. Dzieje się tak wówczas, gdy materią twórczą czyni artysta własną fizyczną obecność w swoich spektaklach, happeningach, swoją pamięć, świadomość i emocje, ale też wtedy, kiedy wykładając swe idee w tekstach teoretycznych, dokonuje jednocześnie analizy bądź rekonstrukcji własnych stanów umysłu, świadomości, a nawet wyobraźni. Zapisy tego typu pozwalają autorowi zobaczyć siebie z zewnątrz, po wielekroć analizować własną świadomość artystyczną, swoją biografię, a także biografię swoich dzieł. Co więcej, projektując określone akty twórcze, projektuje artysta - niejako równoległe wobec tych działań - stany psychiczne.

Język opisu/projektu dzieła jest u Kantora jednocześnie językiem opisu/pro-

1 T. K a n to r, Notatnik 1955... 1958... 1962. W: Metamorfozy. Teksty o latach 1934-1974. Wybór i oprac. K. P 1 e śn i a r o w i c z. Wrocław-Kraków 2005, s. 172. Pisma. T. 1. Dalej do Metamorfoz odsyłam skrótem M. Ponadto stosuję inne skróty do tekstów tego artysty: $\mathrm{D}=$ Dalej już nic. Teksty z lat 1985-1990 (2005). Pisma. T. 3; T = Teatr Śmierci. Teksty z lat 1975-1984 (2004). Pisma. T. 2. Liczby po skrótach oznaczają stronice. Wyróżnienia w cytatach (spacja, wersaliki i czcionka pogrubiona) pochodzą od Kantora, w jednym zaś fragmencie pojawia się moje podkreślenie (spacja i dodatkowo kursywa).

2 A. B e rle a n t, Sensualne i zmysłowe $w$ estetyce. W: Prze-myśleć estetyke. Niepokorne eseje o estetyce i sztuce. Przeł. M. K o r u s i e w i c z, T. M a r k i e w k a. Kraków 2007. 
jektu psychiki, życia wewnętrznego samego artysty. Tekst - podobnie jak w twórczości Tadeusza Różewicza - to zarazem prezentacja świadomości dzieła i świadomości twórcy.

Kantor pokazuje najdosłowniej, że kreowanie jest poznawaniem, doświadczaniem wciąż na nowo siebie samego, własnej przeszłości, wspomnień, ale i doświadczaniem wszystkimi zmysłami swojego ciała, a także materialności „ciała” spektaklu czy obrazu. To sensualne i zmysłowe postrzeganie i przeżywanie świata, własnego dzieła (w wymiarze somatycznym aż po organiczne niemal zespolenie z obrazem, w wymiarze psychicznym aż po utratę przytomności) rozszerza Kantor na myślenie o dziele, które traktuje jak byt żywy. Tworzenie związane po prostu z wysiłkiem psychicznym i fizycznym jawi się jako doświadczanie siebie, ale i doświadczanie własnego dzieła.

Również wtedy, gdy Kantor mówi o rodzących się w nim pomysłach artystycznych, wskazuje na ich dwa zasadnicze źródła, tj. na ciało i świadomość. Dzieło przedstawia się zatem jako byt o naturze biologicznej, żywy organizm, który - jak Różewiczowski Przyrost naturalny - jest nieomal zrośnięty ze swoim twórcą ${ }^{3}$, ale mówi się o dziele również w perspektywie rozmaitych stanów psychicznych, które towarzyszą poczynaniom artysty. Co istotne, oba źródła, z których wyrasta dzieło, traktuje Kantor równorzędnie, wyraźnie zacierając tradycyjnie ostrą granicę między tym, co psychiczne, a tym, co somatyczne ${ }^{4}$. Dualizm ciało-dusza w takim ujęciu traci swój radykalizm. Granica między psyche a soma staje się płynna.

Postawa Kantora ma zatem dwa zasadnicze bieguny. Jeden - wiążąc się z doświadczaniem własnego dzieła i siebie w dziele w wymiarze estetycznym rozumianym jako stan skupienia, koncentracji umysłu i niezwykłego zaangażowania psychicznego ${ }^{5}$ - odsyła do tradycyjnie pojmowanej kategorii aisthesis jako postrzegania za pomocą zmysłów mentalnych, czyli głównie wzroku i słuchu. Drugi biegun ma wymiar somatyczny. Doświadczenie najdosłowniej jawi się tu jako cielesne, „bezpośrednie, niedyskursywne i niejęzykowe [...]”6, jest doświadczeniem własnego ciała i doświadczaniem własnym ciałem, ma przede wszystkim wymiar epistemologiczny, ale w perspektywie somatoestetyki Richarda Shustermana, kategorii ucieleśnienia estetycznego Arnolda Berleanta ${ }^{7}$ czy - ujmując rzecz naj-

3 Zob. na ten temat I. G ó r s k a, Dramat-rzecz i żywy organizm. W: Dramat jako filozofia dramatu na przykładzie twórczości Tadeusza Różewicza. Poznań 2004.

4 W myśli filozoficznej do zbudowania i ugruntowania fundamentów podziału na to, co cielesne, i na to, co duchowe, w którym wyraźnie faworyzowany jest duch, umysł, a deprecjonowane ciało, przyczynił się m.in. P lat o n (np. w Fedonie przedstawia ciało jako takie, które ogranicza możliwości poznawcze człowieka) czy św. P a weł z Tarsu (w Liście do Galatów ukazuje ciało jako źródło pokus utrudniające drogę do zbawienia). Największy wpływ na utrwalenie opozycji ciało-umysł bez wątpienia jednak miał Kartezjański dualizm.

5 W polskiej tradycji estetycznej przyjęły się dwa zasadnicze modele przeżycia estetycznego: W. Ta t a r k i e w i c z a (Skupienie i marzenie. W: Wybór pism estetycznych. Wprowadzenie, wybór i oprac. A. K u c z y ń s k a. Kraków 2004), który wyróżnił dwa rodzaje przeżyć - skupienie i marzenie, oraz R. In g a r d e n a (Przeżycie, dzieło, wartość. Kraków 1966), który akcentował kolejne fazy przeżycia estetycznego i wyodrębnił tu „emocję wstępną" i skupione oglądanie. Zob. też M. W a 11 i s, Przeżycie i doznanie estetyczne. W: Wybór pism estetycznych. Wprowadzenie, wybór i oprac. T. P ę k a la. Kraków 2004.

${ }^{6} \mathrm{~K}$. Wilk o s ze w sk a, Estetyka pragmatyczna. W zb.: Estetyki filozoficzne XX wieku. Red. ... Kraków 2000, s. 130.

7 A. B e r l e a n t, Estetyczne ucieleśnienie. W: Prze-myśleć estetykę. 
ogólniej - w kontekście głoszonej przez Wolfganga Welscha swoistej rekonfiguracji aisthesis ${ }^{8}$ można przypisać temu doświadczeniu również wymiar estetyczny. Wydaje się to tym bardziej zasadne, że Kantor najdosłowniej utożsamia się ze swoim dziełem i percypuje je całym sobą, wszystkimi zmysłami nie tylko przecież w wymiarze doświadczenia osobistego, ale też właśnie w aspekcie estetycznym, skoro własną obecność w dziele i własną pamięć czyni materią twórczą ${ }^{9}$. Wpisanie przeszłości w formę artystyczną sprawia, że zyskuje ona również wymiar estetyczny. Jak odnotowuje Teresa Pękala:

Obcowanie z przeszłością na sposób estetyczny może nas do niej zbliżyć. [...] W estetycznym przeżyciu [...] dochodzi do rozpoznania tożsamości oraz więzów łączących nas ze światem przedstawionym ${ }^{10}$.

Przywoływanie przeszłości w swoim dziele ma na celu - jak się wydaje - jej ponowne doświadczenie zarówno w wymiarze zwykłych ludzkich emocji, jak też w wymiarze estetycznym właśnie.

Martin Jay, zarysowując perspektywę historyczną rozwoju dyskursu na temat doświadczenia estetycznego - począwszy od Kantowskiej propozycji rozumienia doświadczenia jako kontemplatywnego sądu refleksyjnego, aż po Deweyowski projekt sztuki jako doświadczenia - podkreśla, że mimo zasadniczych różnic doświadczenie estetyczne zawsze wiązało się z uprzywilejowaniem (w stosunku do przedmiotu sztuki) podmiotu ,czy to kontemplującego, wytwarzającego, czy też kreującego samego siebie" 11.

W dorobku Kantora to uprzywilejowanie podmiotu jest o tyle niezwykłe, że to sam artysta, twórca swego dzieła, sensu stricto staje się jego częścią. Doświadczanie dzieła jest doświadczaniem siebie. Dokonuje się na obszarze teatru, happeningu, malarstwa, lecz również w pisarstwie, które wiąże się przecież nie tylko z biografiami dzieł Kantora, ale też najdosłowniej z biografią, stanami umysłu, świadomości samego artysty.

Twórczość autora Umarłej klasy ma więc wymiar psychiczny i somatyczny, angażuje bowiem zmysły mentalne i cielesne. Odsyła do postrzeżenia zmysłowego (aisthesis), lecz także do doznawania somatycznego. Szeroko pojęte doświadczenie ujawnia się w teorii, dokonuje się w praktyce, realizuje się poprzez umysł, ale i poprzez ciało, służy doznaniu mentalnemu i cielesnemu siebie, swojego dzieła i siebie we własnym dziele. Zamiast Kantowskiej bezinteresowności pojawia się zaangażowanie. To zaś wymaga podmiotu najdosłowniej ucieleśnionego ${ }^{12}$.

${ }^{8}$ W. W e $1 \mathrm{~s} \mathrm{c} \mathrm{h,} \mathrm{Rekonfiguracja} \mathrm{,,} \mathrm{aisthesis".} \mathrm{W:} \mathrm{Estetyka} \mathrm{poza} \mathrm{estetyka.} \mathrm{O} \mathrm{nowa} \mathrm{postać} \mathrm{este-}$ tyki. Przeł. K. G u c z a ls k a. Kraków 2005. Ta rekonfiguracja polega, zdaniem filozofa, na zakwestionowaniu prymatu widzenia na rzecz innych zmysłów.

${ }_{9}$ Warto w tym kontekście podkreślić, że np. w koncepcji estetyki pragmatycznej J. D e w e y a (Sztuka jako doświadczenie. Przeł. A. P o t o c k i. Wstęp J. Wo j n a r. Wrocław 1975) każde doświadczenie - np. moralne czy poznawcze - może być nacechowane estetycznie, natomiast samo doświadczenie estetyczne nie musi być związane z przedmiotem estetycznym.

${ }_{10}$ T. P ę k a l a, Estetyczne doświadczenie przeszłości. W zb.: Nowoczesność jako doświadczenie. Dyscypliny, paradygmaty, dyskursy. Red. R. Nycz, A. Zeidler-Janiszewska. Warszawa 2008, s. 155.

${ }_{11}$ M. J a y, Pieśni doświadczenia. Nowoczesne amerykańskie i europejskie wariacje na uniwersalny temat. Przeł. A. R e j n i a k- M a j e w s k a. Kraków 2008, s. 231.

${ }_{12}$ Zob. B e r l e a n t, Estetyczne ucieleśnienie. Również R. S h u s t e r m a n (Estetyka prag- 
Podmiot wyposażony zarówno w zmysły dystansu, jak i w zmysły kontaktu, przede wszystkim w dotyk, dekonstruuje kontemplacyjny model „oglądu z dystansu” ${ }^{13}$. Sztuka Kantora, mając swe źródło tak w infernum ciała, jak i w infernum świadomości, żąda też opisu w języku ciała i języku psyche jednocześnie.

\section{Infernum ciala}

Jak zauważa Richard Shusterman: „Ciało wyraża dwuznaczność istoty ludzkiej, będącej subiektywną wrażliwością doświadczającą świata, a zarazem postrzeganym w tym świecie przedmiotem" ${ }^{14}$. Doświadczamy ciała jako źródła percepcji, rozmaitych działań, nie zaś jako przedmiotu własnej świadomości. Uznajemy je za instrument jaźni, ale jawi się też ono jako najbardziej podstawowe medium naszej interakcji ze światem. Jest konieczne dla naszej percepcji, działań, a nawet myśli ${ }^{15}$.

W kontekście rozważań o ciele jako źródle doznań estetyczno-zmysłowych dociekać można - jak proponuje Lilianna Bieszczad - np.: czy da się przy pomocy ciała obserwować przebieg doświadczenia estetycznego? Jaka jest rola ciała i zmysłów w wartościowaniu sztuki? Zapytać też można o to, jaka zachodzi relacja między doznaniem cielesnym a doznaniem zmysłowym, i nawet o to, co rozumiemy przez ciało i zmysły. Inaczej ta kwestia będzie się rysowała, gdy uznamy, że doznania są jednocześnie zmysłowe i cielesne, bo przecież zmysły przynależą do ciała, inaczej, gdy tę tezę radykalnie zmodyfikujemy, przyjmując - jak pisze badaczka:

nie można doznań zmysłowych sprowadzić do fizjologiczno-biologicznych struktur funkcji układu nerwowego, a doznań cielesnych do zdeterminowanych odruchów o charakterze mechanicznym $[\ldots]^{16}$.

Pozostawiając te kwestie otwarte, bo przecież zawsze dyskusyjne, w kontekście twórczości Kantora warto raz jeszcze podkreślić, że tak ciało, jak i umysł są traktowane jako równoprawne źródła percepcji oraz doświadczania siebie i własnego dzieła.

Szczególny jednak charakter twórczości autora Umartej klasy, przede wszystkim tej teatralnej, polega na tym, że w sensie dosłownym wymaga ona uczestnictwa i zaangażowania samego artysty.

Uczestnictwo i zaangażowanie nabierają nowego, wyrugowanego z dotychczasowej estetyki znaczenia, takiego znaczenia, które towarzyszy postawie praktycznej, kiedy to - jak mówił Tatarkiewicz - trzeba coś z przedmiotem zrobić, dotykając go rękami, używając własnego ciała ${ }^{17}$.

matyczna. Żywe piękno i refleksja nad sztuka. Przeł. A. Ch m i elew s ki [i in.]. Wrocław 1998) w swoim projekcie pragmatycznej teorii estetycznej podkreśla, że doświadczenie obejmuje podmiot ucieleśniony, obdarzony wszystkimi zmysłami. W tym kontekście warto przywołać także stanowisko R. B a r t h e s'a, dla którego doświadczenie nie tylko jest kategorią umysłu, ale obejmuje też cielesny wymiar istnienia. Znamiennym przykładem może tu być Przyjemność tekstu.

${ }^{13} \mathrm{~K}$. W il k o s z e w s k a, Doświadczenie estetyczne - strategie pragmatyzacji i zaangażowania. W zb.: Nowoczesność jako doświadczenie, s. 219.

${ }^{14}$ R. S h u s te r m a n, Świadomość ciała. Dociekania z zakresu somaestetyki. Przeł. W. M ałe cki, S. S tanki ew ic z. Kraków 2010, s. 21.

${ }^{15}$ Zob. ibidem, s. 22.

${ }^{16}$ L. B i e s z c z a d, Perspektywy badań nad ciałem w estetyce. W zb.: Wizje i re-wizje. Wielka księga estetyki w Polsce. Red. K. Wilkoszewska. Kraków 2007, s. 475.

17 W il k o s z e w s k a, Doświadczenie estetyczne [...], s. 219. 
W dorobku artystycznym Kantora myślenie w kategoriach somatycznych odnieść należy do samego twórcy, jak i do dzieła. Na jednym biegunie sytuować się będzie zatem cielesna obecność artysty we własnym dziele, a na drugim mówienie o dziele jako o żywym organizmie i związane z tym rozmaite dygresje natury biologicznej, somatycznej, jak chociażby opis swoistej anatomii mowy zawarty w partyturze Umartej klasy ${ }^{18}$.

Twórca Teatru Śmierci własną fizyczność czyni elementem sztuki, która szczególnie jeśli chodzi o spektakle teatralne - bez autora nie istnieje. Ciało artysty zostaje zatem włączone w aktywność estetyczną odbiorcy, ale i samego twórcy. Dosłowna obecność we własnym dziele pokazuje, że bez autora nie jest ono możliwe. „Kantor swoją obecnością na scenie demonstruje nam przesłanie: dzieła sztuki nie można oddzielić od artysty" ${ }^{19}$. Pragnienie bycia na scenie poza wszelką grą, rolą, udawaniem artysta tak opisuje:

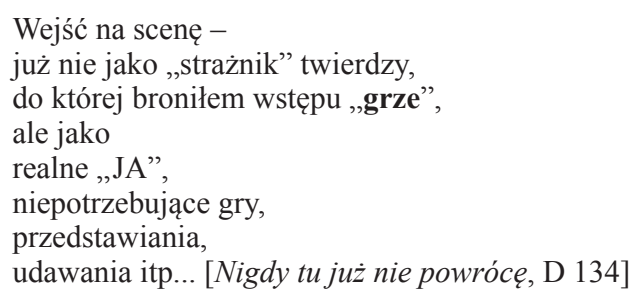

I Kantor przecież na tę scenę wchodzi w znaczeniu dosłownym, gdy pojawia się w swoich spektaklach i swoją obecnością sprawia, że przestrzeń teatralna - jak

${ }^{18}$ Zob. T. K a n to r, Umarla klasa. 〈Partytura〉. T 75-76:

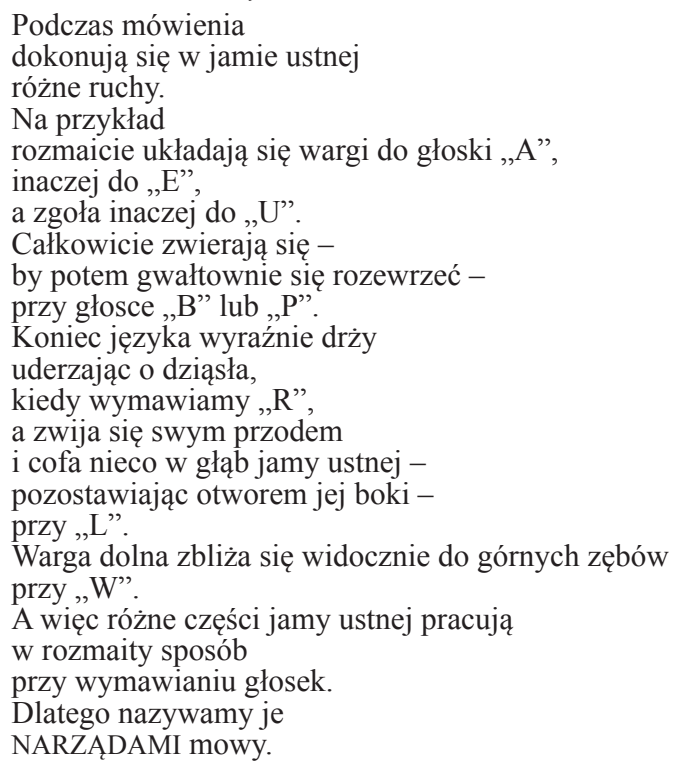

${ }^{19}$ H. S c h mi d, Tadeusz Kantor i niemiecki Bauhaus. Od utopii technologicznej do metafizycznej. W zb.: Sztuka jest przestepstwem. Tadeusz Kantor a Niemcy i Szwajcaria. Red. U. Schorlemmer. Przeł. A. Gr zy bow s ka [i in.]. Kraków 2007, s. 113. 
zauważa Marek Pieniążek - z fikcjonalnej zamienia się „,w przestrzeń możliwą do fizycznego doświadczenia [...]" ${ }^{20}$, ale też wtedy, gdy we własnym pisarstwie autor odkrywa siebie, swoją prywatność.

Dla Kantora mówić o sztuce znaczy mówić o sobie. Artysta podkreśla, że twórczość ma charakter intymny i prywatny. Dlatego w swej działalności wystawia on na ogląd publiczny siebie w sensie fizycznym, ale materią sztuki czyni także bardzo osobiste uczucia, emocje, myśli, zakamarki własnej świadomości i pamięci. Wystawia nawet własną śmierć. W rewii Niech sczezna artyści będzie to projekt umierania twórcy przeznaczony do zrealizowania przez aktora. Kantor złoży bardzo osobiste wyznanie:

Ponieważ AUTOR jest gruźlikiem i wie, że niedługo umrze, tworzy rzadki, chyba unikalny obraz powolnego procesu umierania tejże postaci, czyli samego siebie. [D 23]

Natomiast ostatni spektakl, Dziś sq moje urodziny, w symboliczny sposób potwierdzi, że - najdosłowniej - biografia autora i biografia dzieła utożsamiają się. Twórczość artysty jest zatem próbą siebie w wymiarze psychicznym, ale też fizycznym, biologicznym:

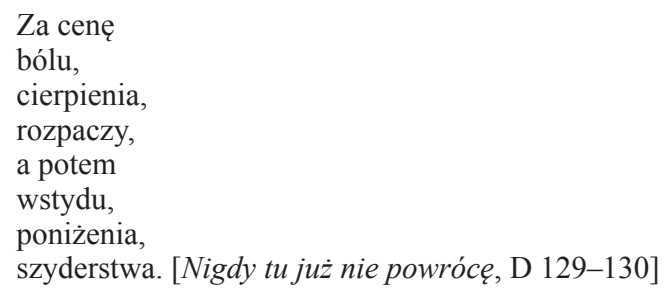

Warto podkreślić, iż tej dosłownej obecności autora we własnym dziele towarzyszy myślenie o procesie twórczym utożsamionym z życiem i o samym dziele jako tworze żyjącym. Autor Umarłej klasy nieustannie zaznacza, że zarówno dzieło, jak i sam akt twórczy wiążą się z ruchem, pulsowaniem, życiem.

Proces twórczy - jak pisze artysta w Teatrze Niemożliwym (Definicji ,procesu”):

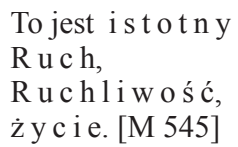

W Notatniku 1955... 1958... 1962 autor Umartej klasy wyrazi pragnienie:

Stworzyć obraz, który byłby

sam w sobie

organizmem żyjącym,

ruchliwym jak

mrowisko. [M 170]

Kantor jest przekonany, że w każdym dziele tkwi jakaś niezależna od twórcy materia pierwotna („UR-MATERIE”), „która kształtuje się sama i w której bytują wszystkie możliwe, nieskończone warianty życia" ${ }^{21}$. Przestrzeń - pierwotną ma-

${ }^{20}$ M. P i e n i ą ż e k, Akt twórczy jako mimesis. „Dziś sa moje urodziny”- ostatni spektakl Tadeusza Kantora. Kraków 2005, s. 83.

${ }_{21}$ T. K a n t o r, 1948... 1949... 1950... Notatnik nocny, czyli metamorfozy. M 109. 
terię - opisuje artysta w kategoriach somatycznych. Nie tylko zatem jawi się ona jako żywa, autonomiczna, ale kurczy się konwulsyjnie, rodzi przedmioty, narzuca im kształty ${ }^{22}$.

Jak można sądzić, to pragnienie ożywiania przedmiotów osiągnie swe ekstremum w realizacji idei bio-obiektów, które, z jednej strony, odsyłają do myślenia o hybrydyzacji, występującej przecież w dziele Kantora niemal od początku jego drogi artystycznej. W tym kontekście warto przywołać np. obrazy z lat 1947-1955, które zaludniają dziwaczne owadopodobne stwory. Z drugiej jednak strony, bio-obiekty - paradoksalnie - odsyłają ku reifikacji, której wymowne przykłady stanowić mogą ,organizmy »analogiczne do ludzkich«, postacie »o strukturze kostnej«, »Z grubsza ciosane«, »zgalwanizowane«, »z form obłych«, figury »zawęźlone«, "obandażowane«, kreślone w różnych skrótach i śmiałych perspektywach" ${ }^{23}$. Warto wymienić też takie przykłady, jak seria ambalaży z lat sześćdziesiątych Emballages, objets, personages, czy np. z r. 1981 Monsieur Ordinaire.

W idei bio-obiektów przedmiot „zrośnięty” z aktorem nie stanowił rekwizytu czy elementu dekoracyjnego. Co godne podkreślenia - to aktorzy byli tu podporządkowani przedmiotowi artystycznemu, byli jego częściami, byli jego ,żywymi o r g a n a m i" - jak napisze artysta w eseju Miejsce teatralne. Jest to niezwykle znaczące podporządkowanie. Przedmioty te wydzielają z siebie „własne »życie«, autonomiczne, nieodnoszące się do FIKCJI (treści) dramatu” (T 397).

Sam Kantor, chociaż, z jednej strony, przedmiotom podporządkowywał aktorów, to z drugiej przyznawał, że ta zależność była tu wzajemna. Przedmiot warunkował działania aktorów, ale sam, bez nich - jak powie artysta - był ,zdezelowanym w r a k i e m" ${ }^{24}$. Bio-obiekty wypadałoby zatem widzieć jako poszukiwanie stanu równowagi między animizacją przedmiotu a reifikacją postaci. Byłyby więc nie tylko - jak chce Krzysztof Pleśniarowicz - ,ilustracją uprzedmiotowienia psychiki w teatrze Cricot 2 " 25 , ale także dosłownie zrealizowaną ideą ożywienia przedmiotów. W odniesieniu do koncepcji bio-obiektów pojawia się myślenie o przedmiocie artystycznym w kategoriach biologii, gdy w Lekcjach mediolańskich Kantor powie wprost, że związek aktora z przedmiotem ma być niemal biologiczny, a w przypadkach określonych przez artystę jako radykalne przedmiot i aktor muszą stanowić jeden organizm ${ }^{26}$. Człowiek i rzecz tworzący bio-obiekt powinni być złączeni niemal genetycznie ${ }^{27}$.

Warto podkreślić, że takie myślenie w kategoriach biologii i genetyki będzie też autor Umarłej klasy odnosił do siebie samego. O poszukiwaniu rozwiązania artystycznego, które pomogłoby wyeliminować i skompromitować proceder przedstawiania, Kantor napisze:

Natrafiłem w końcu na coś, co tkwiło niemal w moich genach.

[. . . . . . . . . . . . . . . . . . ]

Jedynym o d ru che m (artystycznym) jest w tej sytuacji

22 Zob. ibidem, M 111.

${ }^{23}$ L. S t a n g r e t, Tadeusz Kantor. Malarski ambalaż totalnego dzieła. Kraków 2006, s. 23.

${ }^{24}$ T. K a n to r, Miejsce teatralne. T 397.

${ }^{25}$ K. P l e śn i a ro w i c z, Kantor. Artysta końca wieku. Wrocław 1997, s. 205.

26 T. K a n t o r, Lekcje mediolańskie. D 70.

${ }^{27}$ Zob. Ka n to r, Miejsce teatralne, T 397. 
PODRÓŻ DO SWEGO WŁASNEGO INFERNUM, INTROSPEKCJA, POZOSTAWIANIE SWEGO WŁASNEGO Ś L A D U

W PRZESTRZENI „WEWNĘTRZNEJ”. [Notatnik 47, czyli infernum, M 106]

Zatem idea artystyczna jawi się jako ,zaprogramowana” przez naturę, wrodzona. Poszukiwane rozwiązanie - choć uwarunkowane genetycznie - tkwi już nie w sferze biologii, ale w świadomości, we „WŁASNYM INFERNUM".

Biologiczne myślenie o sobie i dziele powraca wielokrotnie. Warto wskazać, że np. działania artystyczne utożsamia twórca Umartej klasy z budowaniem „, k a nk i ży c i a” ${ }^{28}$, obraz określa jako „wydzielinę” swojego wnętrza, „biologiczną materię" swojego organizmu ${ }^{29}$, przyjętą metodę twórczą jako „organiczny stan [...]" ${ }^{30}$, również , pragnienie utrzymania tajemnicy w sferze czystej wyobraźni, [...] niechęć do definitywnego spełnienia - do materialnej realizacji [...]", nazwie artysta swoją , „cechą organiczną" ${ }^{1}$. Znamienne, że w którymś momencie nawet o intelekcie będzie Kantor mówił jako o gruczole, który miałby podniecać jego „namiętność radykalnej awangardy" 32 .

O przedmiocie artysta napisze:

To „coś”, co istnieje na przeciwnym biegunie mojej świadomości, mojego ,ja".

Niedostępne.

I to usiłowanie za wszelką cenę, od wieków, aby go „d o t k n ą ć”.

Przedmiot, który tkwił we mnie głęboko,

teraz odzywał się natarczywie i obiecująco. [Moja twórczość, moja podróż, M 25]

Upersonifikowany przedmiot tkwi w artyście, w ciemnej sferze jego świadomości. Twórca poszukując sposobu na „dotknięcie” tegoż przedmiotu rozważa nawet tak skrajne rozwiązanie jak zjedzenie go, aby móc złączyć się z jego organizmem. Oczywiście, pomysłu tego nie należy traktować dosłownie (sam Kantor oceni go jako zbyt prosty i desperacki ${ }^{33}$ ), ale pokazuje on, jak bardzo somatyczne jest myślenie artysty o sztuce. Tu warto przywołać analogiczny niemal motyw z utworu Różewicza, zaczynającego się od słów:

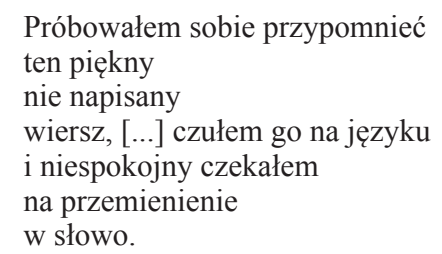

Wydaje się, że wiersz ten - podobnie jak upersonifikowany przedmiot u Kantora - tkwi w ciemnej głębinie nocy? podświadomości? Autor Kartoteki dalej wyjaśnia:

\footnotetext{
${ }^{28}$ T. K a n to r, Notatnik 47, czyli infernum. M 106.

${ }^{29}$ T. K a n to r, Moja twórczość, moja podróż. M 15.

${ }^{30}$ T. K a n to r, Obraz-rysunek. M 113.

${ }^{31} \mathrm{~K}$ a n t o r, Notatnik 47 [...], M 106.

32 T. K a n t o r, Ogólne refleksje. Spirytualizm. T 350.

${ }^{33} \mathrm{~K}$ a n to r, Moja twórczość, moja podróż, M 22.
} 


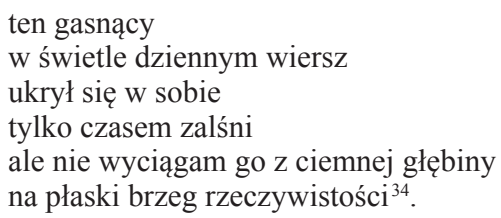

Zatem by wiersz ocalić, należy schować go w ciemności nocy? zawiesić na granicy jawy i snu? podświadomości i świadomości?

Kantorowskim sposobem na wydobycie przedmiotu z ciemnych zakamarków psychiki będzie - paradoksalnie - ukrycie go, umieszczenie w ambalażu, by dzięki temu uczynić go niewidzialnym czy też móc ujrzeć ów przedmiot od niewidocznej strony ${ }^{35}$.

Od biologicznego ujmowania tworzywa artystycznego prowadzi zatem Kantor ku metafizyce. Ambalaż skrywa (lub udaje, że skrywa) przedmiot, pozwala zobaczyć jego niewidoczną stronę. Więcej nawet, w paradygmat myślenia o dziele sztuki wpisane zostaje ludzkie ciało, które już nie jest uchwycone wyłącznie w kategoriach biologicznych, lecz zyskuje również rys metafizyczny, gdy nadaje mu artysta status kruchego, poetyckiego ambalażu:

\author{
szkieletu, śmierci, \\ nadziei \\ przetrwania \\ aż do Sądu Ostatecznego. [Moja twórczość, moja podróż, M 28]
}

\title{
Rekonstrukcje
}

Szczególnie ciekawy w pisarstwie Kantora wydaje się fakt, że mówienie o sobie to jednocześnie mówienie o dziele sztuki. Więcej nawet, mówienie o sobie i o dziele jest już samym dziełem nie tylko wtedy, gdy swoje refleksje ujmuje twórca Teatru Śmierci w formy artystyczne, ale też wówczas, gdy posługuje się formami uznawanymi tradycyjnie za marginalne, brudnopisowe, szkicowe, peryferyjne - jak je sam określa. Można powiedzieć, że właśnie poprzez te formy artysta niemal w sposób dosłowny staje się realizatorem przekonania Luigiego Pareysona głoszącego, iż „działanie w sztuce jest czystym próbowaniem” "36, przy czym zaznaczyć należy, że w przypadku działalności Kantora owo próbowanie nie musi, a nawet nie powinno zostać uwieńczone finalnym dziełem ${ }^{37}$. To właśnie w formach niegotowych, szkicowych artysta odkrywa zakamarki własnej psychiki, utrwala najskrytsze stany ducha, tworząc szczególne „komentarze intymne”. Szczególne, bo odkrywają one intymność artysty, ,intymność” dzieła, którego

34 T. R ó że w i c z, *** (Próbowatem sobie przypomnieć...). W: Na powierzchni poematu $i$ wśrodku. Warszawa 1998, s. 205-206.

${ }^{35}$ Zob. K a n to r, Moja twórczość, moja podróż, M 25.

${ }^{36}$ L. P a r e y s o n, Estetyka. Teoria formatywności. Przeł. K. K a s i a. Kraków 2009, s. 82.

37 Zob. ibidem, s. 82 n. W tym miejscu warto wskazać pewną sprzeczność w postawie T. K a n t o r a (Iluzja i powtarzanie. W: Wielopole, Wielopole. Wrocław 1984, s. 17), który, z jednej strony, postuluje, by „pozostawić próby i tylko próby”, za dzieło uznać projekty, notatki, zapiski intymne i brudnopisy, a z drugiej - swe spektakle podczas wielomiesięcznych prób dopracowuje do perfekcji. 
biografię rekonstruują, ale też własną ,,intymność” tekstu niegotowego, niedopracowanego, „wstydliwego”.

Zapisałem już wiele stron brudnopisów, starając się uchwycić ten sens, który niezmiernie silnie wyczuwam, ale który nieustannie mi się wymyka. Sam go nawet porzucam jako coś „wstydliwego", coś, do czego człowiekowi „rozumnemu” nie wypada się przyznawać publicznie. [Wielopole, Wielopole. Notatki reżyserskie. T 328]

Kantor nie ukrywa jednak ani form uznawanych za brudnopisowe, ani własnych bardzo osobistych przeżyć, emocji, stanów świadomości. Przeciwnie, przedkłada to, co nieukończone, nieuładzone nad gotowe dzieło, to, co żywiołowe, instynktowne, nad to, co rozumne. Pisanie rozjaśnia to, co niezrozumiałe, prowadzi na powierzchnię, pozwala zrekonstruować przebieg procesu twórczego, ale też towarzyszące kreowaniu stany umysłu, świadomości, wyobraźni.

Kantor deklaruje np.: „Pragnę dokładnie opisać ten mój ówczesny »stan duchowy «, mój »l'état d'âme« [...]"38, lub odtwarza proces myślenia dotyczący konkretnego działania artystycznego. Podejmuje np. próbę rekonstrukcji p r z e dostatniego etapu myślenia o Powrocie Odysa, stara się go ożywić z pamięci, odtworzyć pierwsze olśnienie, pierwszą refleksję, fascynację, „kiedy się coś w sobie i dla siebie odkrywa" ${ }^{39}$. Pojawia się zatem motyw rekonstrukcji nie samego dzieła, lecz stanu umysłu, myślenia o dziele, próba odtworzenia impulsu, który zapoczątkował działania artystyczne. Rekonstrukcja procesu twórczego jest tu zatem równocześnie rekonstrukcją własnej świadomości artysty, wyobraźni, ale też pierwotnego doświadczenia dzieła istniejącego wówczas jedynie w sferze projektu, idei. W kontekście tego problemu znamienny wydaje się jeden z autonomicznych tekstów umieszczonych w tomie Teatr Śmierci zatytułowany Imaginacja wykonalność nieudana. Tekst rozpoczyna się od swoistej rekonstrukcji stanu wyobraźni:

...wyobraziłem sobie, że oddział żołnierzy, pokątnie „koczujący” w POKOJU, w tym pokoju mojego dzieciństwa, istniejącym już tylko w pamięci, że ten oddział rekrutów, wycofany z życia i porzucony gdzieś w kącie pokoju, jak nikomu niepotrzebna „klisza” ongiś pamiątkowego zdjęcia - ustawiony jest na ruchomej platformie. [T 355]

Następnie to, co wyobrażone, zostaje ukazane na rysunku. „Wykonałem rysunek" ${ }^{40}$ - stwierdza dalej artysta i przedstawia jego krótką charakterystykę. Po czym ocenia: „Pomysł był świetny [...]”, i wreszcie wyjaśnia, dlaczego dokonuje jego szczegółowej rekonstrukcji:

...piszę to wszystko nie po to, aby opisywać własne pomysły; chodzi mi o przekazanie pewnych wniosków, wydaje mi się dość ważnych dla pracy scenicznej. ...bo w kolejności pomysł platformy spowodował myślenie o jego WYKONALNOŚCI; o wymyśleniu takiego urządzenia (posługującego się niestety motorem), aby udźwignęło 9 osób. No i żeby ruszyło.

Po tym, wydawałoby się, technicznym zwycięstwie z przykrością stwierdziłem, że cała poezja i lekkość wspomnienia ulotniły się bezpowrotnie [...]. [T 355]

${ }^{38} \mathrm{~K}$ a n to r, Miejsce teatralne, T 369.

39 Ibidem, T 367.

${ }^{40}$ Warto w tym miejscu podkreślić, że dla Kantora rysunek nie był ćwiczeniem, wprawką do projektowanego dzieła, lecz ,ćwiczeniem” wyobraźni. W żadnym razie nie był jej materializacją. Zob. K a n t o r, Obraz-rysunek, M 114. 
W tym miejscu porzuca artysta problem platformy i umieszczonych na niej „biednych żołnierzy”, gdyż - jak stwierdza - bardziej interesuje go wniosek płynący z opisanego doświadczenia:

MYŚLENIE O WYKONALNOŚCI [...] ODDALA OD ŚWIATA IMAGINACJI! [...] IMAGINACYJNOŚĆ nie leży w spełnieniu, lecz w marzeniu, w niemożliwości czy niezdolności zrealizowania, więcej: w NIEUDANIU SIĘ [...]. [T 356]

Zdaniem Kantora, owo „NIEUDANIE SIĘ” powinno być celem samym w sobie, ono właśnie pozwala dotrzeć do świata wyobraźni, która dla twórcy jest najważniejszym czynnikiem sztuki ${ }^{41}$, tym miejscem, gdzie kształtuje się wrażliwość, gdzie rodzą się artystyczne ,idee, pomysły, przedmioty, sytuacje..." ${ }^{42}$ Wyobraźnia stanowi ten element, który tkwi w samym środku procesu twórczego, ,jest stale w pogotowiu, w napięciu, replikująca natychmiast na to, co napływa z zewnątrz" ${ }^{43}$. Owo Kantorowskie „NIEUDANIE SIE,” odsyła do myślenia o dziele w kategoriach niedoskonałości ${ }^{44}$.

Rekonstrukcja procesu twórczego - od wy obrażenia (,wyobraziłem sobie"), przez realizację konceptu w formie rysunku (,wykonałem rysunek"), j e g o o c en ę (,pomysł był świetny”), usprawi ed liwienie faktu opisywania powziętej idei (,chodzi mi o przekazanie pewnych wniosków”), aż po myśl o realizacji scenicznej (,,pomysł platformy spowodował myślenie o jego WYKONALNOŚCI [...]") - okazuje się j e dnocześnie rekonstrukcją stanu umysłu, wyobraźni, świadomości artystycznej. Kantor podkreśla, że klarowność i logikę wyrazu dzieła zawsze poprzedzają towarzyszące procesowi tworzenia stany ciemne i patologiczne ${ }^{45}$. Opisuje je jako chorobliwe, bliskie obłędu, wprawiające w rozpacz i bezsilność, ale - jak konkluduje - to one ostatecznie prowadziły do udanych rozwiązań, trafnych i jasnych ${ }^{46}$. W tym procesie rekonstrukcji własnego doświadczenia z przeszłości - mówiąc słowami Richarda Shustermana - „doświadczający podmiot kształtuje i jednocześnie sam jest kształtowany" ${ }^{47}$.

\section{Reinterpretacje}

W twórczości Kantora wynikiem rekonstrukcji dawnych idei i stanów świadomości często jest ich reinterpretacja. Jak z klisz pamięci buduje autor Umarlej klasy swój teatr, tak też przeszłość nieustannie ożywia w swoim pisarstwie. Ogląda tam własne idee artystyczne, rekonstruuje poglądy, omawia dokonania twórcze, ale wszelkie te działania są jednocześnie reinterpretowaniem własnej świadomości artystycznej, stanów umysłu, siebie samego sprzed lat. Wielokrotnie przygotowuje Kantor podsumowania całej swej twórczości, poszczególnych jej etapów, przeformułowuje lub rozwija wybrane idee. Wypowiedzi o charakterze konkluzji,

${ }^{41}$ T. K a n t o r, Rewindykacje. T 428.

${ }^{42} \mathrm{~K}$ a n t o r, Obraz-rysunek, M 113.

${ }^{43}$ T. K a n to r, Abstrakcja umarła, niech żyje abstrakcja. O sztuce informel. M 169.

${ }^{44}$ Zob. A. J. G r e i m a s, O niedoskonatości. Przeł., posł. A. G r z e g o r c z y k. Poznań 1993.

${ }^{45}$ T. K a n t or, Wielopole, Wielopole. Notatki reżyserskie. T 328.

46 Ibidem.

${ }^{47} \mathrm{~S}$ h u st e r m a n, Estetyka pragmatyczna, s. 99. 
reinterpretacji jego drogi twórczej są rozsiane po wszystkich niemal pismach artysty.

Spośród licznych przykładów warto przywołać tekst Ja realny, odnoszący się do spektaklu Nigdy tu już nie powrócę. Poddaje tu bowiem Kantor radykalnej rewizji zasadniczą dla swej twórczości ideę realności i związaną z nią kwestię gry. Pyta sam siebie:

Jak to było naprawdę

$\mathrm{z}$ tą realnością.

Czy rzeczywiście zrobiłem wszystko dla niej? [D 132]

Na temat gry dalej powie:

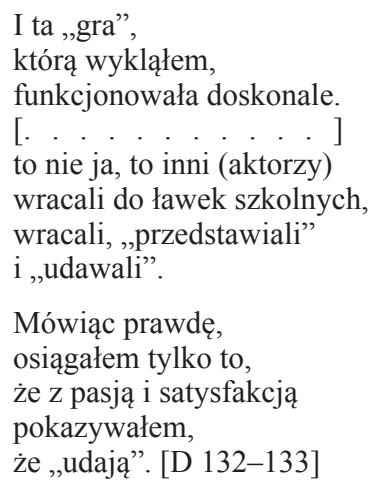

Następnie artysta przyznaje:

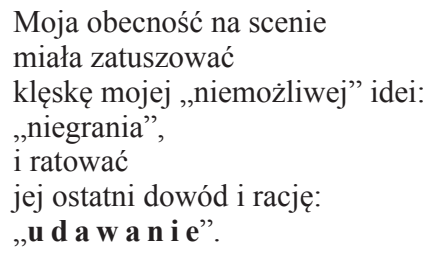

Ale w głębi duszy nie rezygnowałem. [D 133]

Obnaża zatem twórca swą świadomość, przyznaje otwarcie, że był dumny z własnego radykalizmu, a jednocześnie nie ukrywa, że nie wierzył w pełną możliwość realizacji poczynionych założeń artystycznych. Kantor oświadcza, iż „na boku" oddawał się wątpliwościom, ale paradoksalnie stwierdza, iż taka postawa mogła być przyczyną atrakcyjności jego spektakli. Zapewnia jednak, że nie porzuca idei realności.

W kontekście reinterpretowania dorobku artystycznego warto chociażby wymienić teksty, który stanowią całościowe podsumowanie spuścizny Kantora. To przede wszystkim Moja twórczość, moja podróż, zredagowany przez autora w r. 1988 „kolaż z notatek, manifestów i esejów pisanych przez całe życie”48, esej Miejsce

${ }^{48}$ K. P leśn i a row i c z, Nota edytorska. M 575. 
teatralne, $w$ którym, począwszy od Teatru Niezależnego, raz jeszcze przygląda się autor Umarlej klasy swojej wędrówce artystycznej z perspektywy ukończonego właśnie spektaklu Wielopole, Wielopole i tekstu Rewindykacje. Komentarz historyczno-teoretyczny do scenariusza wystawy ,20 lat działalności teatru Cricot 2”, w którym znowu twórca prezentuje swe najważniejsze idee teatralne.

Nieustannie we wszystkich tych tekstach pojawiają się dygresje, sprostowania, definicje tych samych pojęć, próby wyjaśniania czy rozwinięcia po raz kolejny najistotniejszych założeń artystycznych, podkreślanie z maniakalnym uporem własnego pierwszeństwa niemal we wszystkim. W eseju Miejsce teatralne, powracając do swojej koncepcji teatru opartej na odrzuceniu pojęcia, ale i samej praktyki przedstawiania, artysta powtarza: „PRZYPOMINAM MOJĄ DATĘ: ROK 1944!” (T 378). To przypomnienie powróci jeszcze wielokrotnie przy okazji rewindykacji innych idei twórczych. Patrząc z dystansu, będzie też Kantor odnajdywał swe rozmaite koncepcje artystyczne na tych etapach swojej działalności, gdy nie były one jeszcze nazwane (np. idea ,przedmiotu biednego" zrodzona w Teatrze Podziemnym w r. 1944, w r. 1960 na etapie Teatru Informel zyska miano Realności Najniższej Rangi).

Wydaje się, że na dzieło Kantora - podobnie jak u Różewicza - składa się właśnie cały proces twórczy, od prezentacji zamysłu, owego pierwotnego impulsu, przez rozmaite stany emocjonalne, psychiczne, próby, korekty, aż po spektakle i rodzące się z nich teksty (zapiski, notatki, projekty, partytury itp.).

Wciąż na nowo budowany autokomentarz przedstawia dzieło, jest jego biografią, ale i biografią twórcy i jego autoportretem psychicznym. Akt pisania daje artyście możliwość, by zobaczyć siebie z zewnątrz, powrócić do przeszłości, doświadczyć jej raz jeszcze. Jednak warto podkreślić, że - jak odnotowuje Dominick LaCapra - „to, do czego odnosimy się jako do doświadczenia, jest zazwyczaj pamięcią doświadczenia" "49. Właśnie tę pamięć doświadczenia ożywiał Kantor w swoich spektaklach, ale też w pisarstwie, które pozwoliło uchwycić, to, co zapamiętane, by móc do tego powracać, by lepiej się utrwalonym w pamięci doświadczeniom przeszłości przyjrzeć, by doznać ich raz jeszcze, by wreszcie je skorygować. To język uczynił artysta medium pośredniczącym i utrwalającym jego przeżycie sztuki, własnego dzieła i siebie. Twórczość artysty mieści się w formule, którą odnajdujemy u Franka Ankersmita:

\footnotetext{
Nasze doświadczenie świata, sposób, w jaki doświadczamy rzeczywistości, czy też sposób, w jaki rozważamy nasze doświadczenie i naszą wrażliwość na doświadczenie, wszystko to przesiąknięte jest językiem $^{50}$.
}

Może właśnie dlatego Kantor nieustannie odczuwał wewnętrzny przymus pisania o sobie i swoim dziele?

${ }^{49}$ D. L a C a p r a, Historia w okresie przejściowym. Doświadczenie, tożsamość, teoria krytyczna. Przeł. K. B o j a r s k a. Kraków 2009, s. 88.

${ }^{50}$ F. A n k e r s m it, Język a doświadczenie historyczne. W: Narracja, reprezentacja, doświadczenie. Studia z teorii historiografii. Red., wstęp E. D o m án s k a. Kraków 2004, s. 224 (przeł. S. Sikora). 


\section{Projekty}

Pisarstwo autora spektaklu Wielopole, Wielopole - tak jak pozostałe obszary jego aktywności artystycznej - jest wyrazem niezwykle silnego emocjonalnego zaangażowania w akt kreacji, dosłownego niemal zrośnięcia się z dziełem, dowodem, że nie można wyznaczyć granicy między życiem a twórczością ${ }^{51}$. Jawi się jako swoista próba odtworzenia stanów umysłu, świadomości, pamięci, idei. Jednak obok rekonstrukcji pojawiają się też projekty. Mają one szczególny charakter, gdyż Kantor projektuje nie tylko konkretne działania artystyczne, ale nawet uczucia i emocje, jakie tym działaniom powinny towarzyszyć. Zarysowując np. idee Teatru Zerowego, prowadzące, „w kierunku pustki i »okolic zerow y c h «" ${ }^{52}$, artysta jednocześnie określa działania, które mają stwarzać pozory takich stanów psychicznych, jak np.:

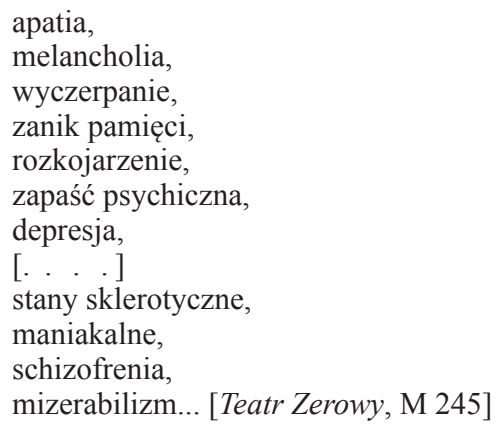

Mamy tu do czynienia z projektem stanów psychicznych i somatycznych, który jest po prostu zadaniem aktorskim i jest to, oczywiście, projekt możliwy do wykonania. Kantor jednak idzie dalej, projektując stany towarzyszące samemu aktowi tworzenia, ale też przeżywania, doświadczania dzieła. Byłby to zatem również projekt doznań dla odbiorcy?

W Litanii sztuki informel artysta wylicza -

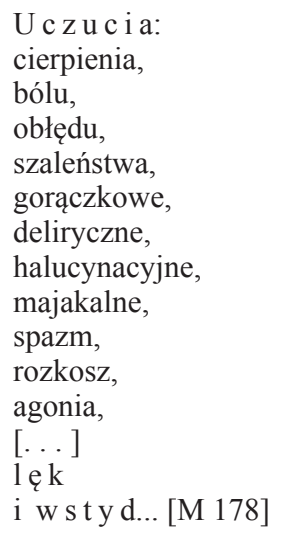

51 Warto w kontekście utożsamienia sztuki i życia znów przywołać stanowisko D e w e y a (op. cit.), którego zdaniem w obu formach doświadczenia - zarówno w doświadczeniach życiowych przenikniętych jakością estetyczną, jak i w doświadczeniach sensu stricto estetycznych - życie staje się sztuką. Zob. też W i 1 k o s z e w s k a, Estetyka pragmatyczna, s. 120.

${ }_{52}$ T. K a n t o r, Teatr Zerowy. M 245. 
Wyliczenie tych doznań, stanów ciała i ducha towarzyszy opisowi bezforemnej materii, „najniższych czynności [...]”, „Przedmiotów bi e d ny ch [...]” i „Mizernych zabiegów wokół tego in fe r n u m [...]” (M 179). Również w innym tekście poświęconym sztuce informel (Informel. Hasła-definicje) obok sposobów traktowania materii (np. stłoczenie, zgniecenie), różnych jej rodzajów (np. ziemia, błoto), materiałów i przedmiotów (np. łachmany, szmaty), a nawet obyczajów i zachowań (np. rozwiązłość, rozwydrzenie) wylicza Kantor stany emocjonalne, które określa jako patologiczne. Są to:

EKSCYTACJA
EGZAGERACJA
STANY HALUCYNACYJNE
STANY GORACCZKOWE
STANY MAJAKALNE
STANY DELIRYCZNE
STANY KONWULSYJNE
STANY AGONALNE. [M 185-186]

Wymienione stany można nazwać granicznymi. Odsyłają bowiem do myślenia o świadomości, ale i o ciele, mają wymiar psychiczny, ale są też przeżywane fizykalnie, biologicznie. Sam Kantor, powracając do rozważań o stanach emocjonalnych towarzyszących procesowi tworzenia, w innym tekście spod znaku Teatru Informel stany te będzie wiązał raczej z somatyką:

\author{
Te biologiczne stany \\ przez niezwykłą temperaturę \\ tracą wszelkie związki z praktycznym życiem, \\ stają się materią sztuki. [Teatr Informel, M 190]
}

Projekt dzieła jawi się zatem jako projekt przeżyć, emocji psychicznych i somatycznych. Stany uczuciowe potraktowane jako materia twórcza zostały tu przypisane konkretnej idei artystycznej. Wydaje się, że nie należy tego projektu pojmować dosłownie. Nie da się przecież zaprogramować określonego uczucia, które miałoby towarzyszyć konkretnym działaniom artystycznym czy przeżywaniu sztuki. Jest to jednak z pewnością wyraz ogromnej wrażliwości emocjonalnej Kantora, wyraz świadomości, że kreowanie wymaga bezgranicznego zaangażowania nie tylko w sensie fizycznym, ale i psychicznym.

Twórczość artystyczna jest aktem obnażania najskrytszych tajemnic własnej psychiki, jest doświadczaniem siebie. Tworzyć oznacza przeżywać, doświadczać najrozmaitszych emocjonalnych stanów granicznych, świadomych i podświadomych. Dzieła doznaje się niemal fizykalnie - od bólu, cierpienia, po rozkosz i agonię. Tworzyć to znaczy dla Kantora zejść do infernum, infernum własnego wnętrza.

\title{
Infernum świadomości
}

Od ciała, przez wyobraźnię, świadomość, psychikę, wiedzie twórca Teatru Śmierci ku stanom ducha, mocom infernalnym. Ujarzmienie własnego wnętrza, uporządkowanie myśli, emocji, opanowanie instynktów skutkuje powstaniem dzieła sztuki. Jednak istotne jest to, iż akt tworzenia dokonuje się właściwie niezależne od woli artysty. Mówi on, że gdy zaczyna myśleć o kreowaniu, gdy szuka jakiegoś logicznego związku dla uzasadnienia wyboru określonych elementów, to 
czuje „uporczywie pulsujące, jakby sygnały »s k ąd ś«, czuje, że mają swoją wspólną przyczynę [...]”. Stwierdza nawet, iż odnosi wrażenie, że „kieruje nimi jakaś ręka, jakaś nieznana siła" 53 . Skojarzenie z Różewiczowskim wyznaniem z Przygotowania do wieczoru autorskiego jest nieodparte:

mam [...] wrażenie, że nie zawsze panuję nad kierunkiem. Od pierwszej wystawionej przez teatr sztuki, którą zacząłem pisać w roku 1958, jakaś siła spychała mnie w bok... ${ }^{54}$

Dla Kantora tworzenie okazuje się zatem doświadczaniem, eksploatowaniem własnego wnętrza, tajemniczych infernalnych mocy. W Lekcjach mediolańskich artysta powie:

SZTUKA NIE JEST PSYCHOLOGIĄ, PROCES TWÓRCZY JEST
DALEKI OD NAUKOWEGO BADANIA.
W SZTUCE NALEŻY P S Y C H I K Ę PRZYJĄĆ, A NIE BADAĆ!
PRZYJĄĆ JAKO POJĘCIE POZAZMYSŁOWE. [D 94]

W pisarstwie Kantora, niemal obsesyjnie, powraca motyw infernum. Twórca wyznaje:

Infernum. To było moje „W N Ę T R Z E”,

gdzie kłębią się namiętności, żądze, wszystkie pasje,

rozpacz i rozkosz, żale przeszłości i jej tęsknoty, i pamięć

wszystkiego, i myśl trzepocząca się jak ptak w czasie burzy. [Moja twórczość,

moja podróż, M 15]

Wnętrze pełne kotłujących się myśli, uczuć, emocji, często sprzecznych, niezrozumiałych jawi się - jak pisze artysta - jako wulkan, pole walki i cela żarliwych rozmyślań. Tam bierze swój początek dzieło. Wyrasta ono z tych stanów niejasnych, niejednoznacznych, nieuświadomionych, delirycznych, ekstatycznych, halucynacyjnych, tkwiących na pograniczu życia i śmierci. Akt twórczy niesie przedsmak umierania, jawi się jako ,powiew Śmierci [...]”. Artysta zastanawia się nawet, czy to nie ta „Piękna Pani [...]”- jak ją nazywa za Gordonem Craigiem - rządzi w sztuce [M 15].

Tworzenie sytuuje się na granicy szaleństwa, obłędu, dzieje się poza rozumem. Chęć realizacji określonych idei twórczych jawi się jako opętanie ${ }^{55}$. Ten „brak »rozkazów« wysyłanych z naszego mózgu, które powodują działania »rozumne «"56, czyni autor Umarłej klasy swoim wyznaniem wiary. Rola nieuświadomionych sił $\mathrm{w}$ akcie twórczym jest nie do przecenienia. Wielokrotnie powracają w pismach Kantora refleksje, w których o działaniach artystycznych mówi się jako o aktach nieświadomych. Siłą sprawczą stają się tu przeczucie, instynkt, intuicja:

${ }^{53}$ T. K a n to r, Niech sczezna artyści. Rewia. D 9. Warto zaznaczyć, że niemal identyczną opinię formułuje artysta w rozmowie z K. M i k la s z e w s k i m (Spotkania z Tadeuszem Kantorem. Kraków 1992, s. 121). Kantor, odcinając się tu od metafizyki, rozwinie tę myśl tak: „Na pewno nie jest to ręka Boga. Nie chcę tego tłumaczyć metafizycznie, ale odbieram wiele impulsów, otrzymuję dużo sygnałów, czuję wyraźnie bliżej niewytłumaczalne ich źródło”. Wydaje się, że to „,niewytłumaczalne źródło" każe jednak - wbrew intencji artysty - myśleć o metafizyce.

${ }_{54}$ T. Ró ż e w i c z, Przygotowanie do wieczoru autorskiego. W: Proza. T. 3. Wrocław 2004, s. 240. Utwory zebrane.

55 Zob. np. fragment pt. Meditations Illusion - Reje dotyczący spektaklu Dziś sq moje urodziny (D 244).

${ }^{56} \mathrm{~K}$ a n t o r, Moja twórczość, moja podróż, M 15. 

M 10]

Instynktownie czuję, że należy przekroczyć próg widzialności. [Notatnik 47, czyli infernum,

\section{Działałem [...]}

w dużej mierze instynktownie. [Moja twórczość, moja podróż, M 27]

O parasolu jako o przedmiocie artystycznym twórca napisze: „...przeczuwam, że może być przydatny do moich celów" ${ }^{57}$.

Mówiąc o malarstwie, dobitnie artysta stwierdzi, że ma po prostu „wstręt do pewnej siebie / kontroli »Świętej Świadomości« [...]" ${ }^{58}$.

Gdzie indziej wyzna:

Pomimo mojej wiary w siłę świadomości, przekonuję się nieustannie, jak bardzo instynkt, podświadomość, intuicja kierują nieomylnie naszymi poczynaniami w sztuce. I że świadomość jest tylko anektowaniem tamtej sfery i oczywiście rozwijaniem. [Obraz-rysunek, M 113]

Natomiast sam opis aktu twórczego staje się jednocześnie autoportretem psychicznym artysty:

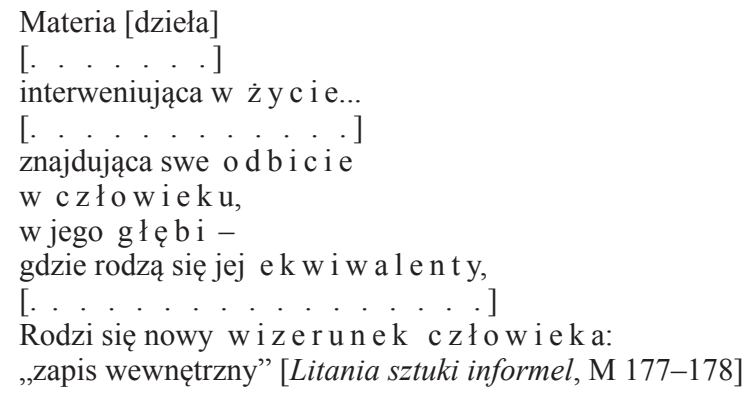

Autor utożsamia się ze swym dziełem, które staje się jego ,zapisem wewnętrznym". Tworzenie jest zatem aktem dokonywanym nie tylko na materii artystycznej, zewnętrznej wobec twórcy, ale też na własnej psychice artysty. Sztuka jawi się jako otwarcie swego wnętrza, lecz także jako rodzaj spowiedzi. Kantor wyznaje, że nawet problemy sumienia przekształca w formy ,artystyczne" ${ }^{59}$.

Niewątpliwie jednak u autora Umarłej klasy ,zapisowi wewnętrznemu” towarzyszy „zapis zewnętrzny”, którym są materialne ślady obecności twórcy we własnym dziele. Wydaje się, że w sztuce Kantora świadomość własnego dzieła wiąże się najdosłowniej z jego fizykalnym doświadczaniem, poznawaniem, kształtowaniem. Będzie to naznaczanie własną cielesnością, głównie poprzez dotyk, swych spektakli, ale przede wszystkim prób do nich, prezentowanie konkretnych działań scenicznych, usadzanie aktorów w określonych pozach, poprawianie ich kostiumów, ustawianie rekwizytów, lecz będzie to również wyjątkowe zaangażowanie emocjonalne, wyrażone sensu stricto ciałem - przez dynamiczną ekspresję gestów, mimikę, aż po niezwykłe zjednoczenie artysty z obrazem. Angażując się w swoją twórczość, najdosłowniej fizycznie, cieleśnie, staje się dzięki temu artysta (mówiąc słowami Pieniążka) ,idealnym widzem własnego spekta-

\footnotetext{
${ }^{57} \mathrm{~K}$ a n t o r, Notatnik 47, czyli infernum. M 107.

58 T. K a n t o r, Przedruk rękopisu z roku 1960, z okresu montowania Teatru Informel. M 187.

59 T. K a n to r, Interwencje. D 167.
} 
klu" ${ }^{60}$. Percypuje swe dzieło nie z zewnątrz, z dystansu, lecz od środka, w trakcie procesu twórczego, który już sam jest dziełem - jak wielokrotnie podkreślał Kantor - i w którym artysta jest nie tylko twórcą, ale też „tworzywem”, częścią własnego dzieła.

Szczególnym zapisem śladów fizyczności artysty wydaje się przede wszystkim obraz, który w odróżnieniu od ulotnych form, jak spektakl czy happening, jest znacznie trwalszy: „Obraz ma to do siebie, że jest nie tylko sposobem ukazywania obrazowanej rzeczy, lecz ponadto sam jest rzeczą postrzeganą" ${ }^{61}$. Idąc - za Iwoną Lorenc - tropem rozważań Edmunda Husserla, można mówić o dwóch płaszczyznach obrazu: w znaczeniu fizycznym (to np. płótno pokryte farbą) i w znaczeniu przedmiotu („Bildobjekt”, który jest określoną organizacją koloru i formy). Tego ostatniego nie należy mylić z „Bildsujet”, będącym obrazem imaginacji i mającym swe źródło w fantazji ${ }^{62}$.

W kontekście somatyki i niezwykłego cielesnego zaangażowania Kantora we własne dzieło szczególnie ważne wydaje się to pierwsze Husserlowskie rozumienie obrazu, który w sensie dosłownym rejestruje np. pociągnięcia pędzla, nierównomierne rozłożenie farby, ale też takie ślady pozostawione przez artystę, jak odciski palców, dłoni, podpis. Wszystko to stanowi rejestr fizykalnych znaków, sygnatur pozostawionych przez twórcę. Warto wszakże podkreślić, że nawet te pozornie trwałe odciski wkomponowane w obraz z czasem słabną, blakną, wycierają się. Starzeje się sama materia dzieła, blaknie płótno, płowieją kolory, autorski podpis się zaciera. Patyna czasu może mieć jednak - jak zauważa Pareyson - „pewien aspekt estetyczny, ponieważ bezpośrednio dotyka materii sztuki, która tracąc pewne cechy, zyskuje inne, nowe, nieprzewidziane na początku, lecz tak pasujące do dzieła, że nie da się ich od tegoż oddzielić" ${ }^{63}$.

Te wytarte ślady, wyblakłe kolory stanowią zatem swoiste znaki obecności twórcy, którego już nie ma. Za Janem Kottem można powtórzyć, że to, co z nas zostaje, jawi się jako esencja - „Esencją jest ślad. Jak odcisk skorupiaka na kamieniu jeszcze nie do końca rozmyty przez wodę" ${ }^{64}$.

Obecność artysty utrwalona w obrazie w twórczości Kantora jednak nie tylko ma wymiar materialny odcisku, śladu, sygnatury. Jest również zapisem niezwykłego, nie wyłącznie somatycznego, ale też emocjonalnego zaangażowania twórcy $\mathrm{w}$ proces artystyczny, w samo dzieło, wyrazem wewnętrznego przeżycia transu, ekstazy towarzyszącej kreowaniu aż do utożsamienia z obrazem, stanowi dosłowną ilustrację słów Martina Heideggera, że ,artysta jest źródłem dzieła. Dzieło jest źródłem artysty" ${ }^{65}$.

${ }^{60}$ M. P i e n i ą ż e k, Tadeusz Kantor-idealny widz własnego spektaklu. W: Akt twórczy jako mimesis, s. 80.

${ }^{61}$ I. L o r e n c, Świadomość i obraz. Studia z filozofii przedstawiania. Warszawa 2001, s. 125. Warto zaznaczyć, że również np. Ingarden, odkrywając warstwową strukturę dzieła literackiego, ale też dzieł należących do innych dziedzin sztuki, podkreślał, iż w przypadku obrazu należy odróżnić sam obraz od jego podstawy fizycznej, czyli po prostu pokrytego farbą podłoża.

${ }_{62}$ Zob. ibidem, s. 125.

${ }_{63} \mathrm{P}$ a r e y s o n, op. cit., s. 132.

${ }^{64}$ J. K o t t, Kadysz. Strony o Tadeuszu Kantorze. Oprac. P. Kł o c z o w s k i. Wyd. 2, zmien. Gdańsk 2005, s. 15.

${ }^{65}$ M. H e i d e g g e r, Źródło dzieła sztuki. W: Drogi lasu. Przeł. J. M i z e r a. Warszawa 1997, s. 7. 
W notatkach do rewii Niech sczezna artyści Kantor napisze:

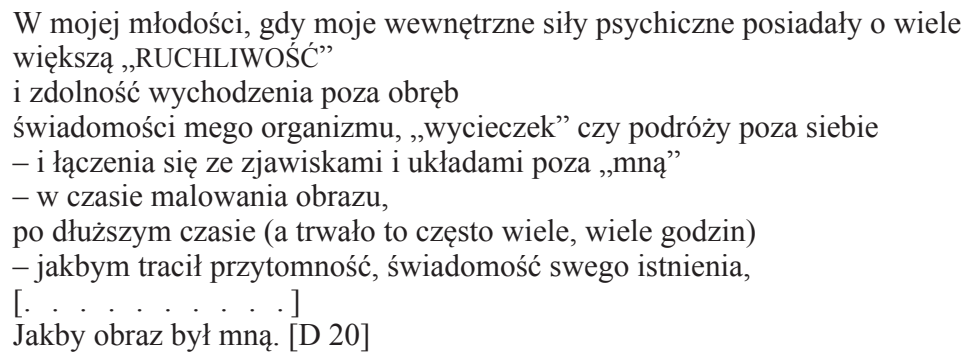

Przedstawioną przez Kantora sytuację można opisać słowami autora $O k a$ i umystu: „działanie i doznawanie [są tu] tak trudne do rozróżnienia, że już nie wiadomo w końcu, kto widzi, a kto jest widziany, kto maluje, a kto jest malowany" ${ }^{66}$.

Aktywna obecność ludzkiego ciała w doświadczaniu przez artystę własnego dzieła i siebie, własnej fizyczności odsyła do kategorii ucieleśnienia, która w przedstawionej sytuacji malowania obrazu jest jej dosłowną realizacją. Ucieleśnienie jawi się tu po prostu jako zjednoczenie obrazu z ciałem artysty czy też jako inkarnacja, umieszczenie $\mathrm{w}$ ciele ${ }^{67}$. Nie wiadomo już, czy to obraz utożsamia się ze swym twórcą, czy twórca z obrazem. Zespolenie osiąga tu niezwykłą pełnię dzięki obecności ciała i szczególnej koncentracji zmysłów, która - jak odnotowuje Berleant - kojarzy się z doświadczaniem sztuki ${ }^{68}$. Warto też powtórzyć za twórcą książki pt. Prze-myśleć estetykę:

W ucieleśnieniu znaczenia są raczej doświadczane niż poznawane rozumowo. To znaczy, próbujemy je pojąć naszymi ciałami, dosłownie ogarniamy je tak, że odczuwamy je cieleśnie ${ }^{69}$.

W kontekście percypowania i doznawania własnego dzieła poprzez ciało można powiedzieć słowami autora Fenomenologii percepcji, iż ,jeśli postrzega się swoim ciałem, to ciało jest pewnym naturalnym Ja i jakby podmiotem postrzegania"70. Natomiast „wycieczki” sił psychicznych poza świadomość organizmu twórcy - o których wspomina Kantor - odsyłają do myślenia o nieredukowalnych związkach i zależnościach psyche i soma. Ciało jest dla autora Umartej klasy jednym z zasadniczych źródeł dzieła sztuki, jest rodzajem inkubatora, w którym dojrzewają pomysły artystyczne, ale pozwala też w sposób szczególny doświadczać własnego dzieła aż do zatracenia. Co istotne, to ciało warunkuje stan umysłu, świadomości i odwrotnie (umysł, świadomość wpływają na kondycję ciała). Przedstawiona przez artystę sytuacja malowania obrazu dowodzi, mówiąc słowami Berleanta, że „nie istnieje świadomość bez ciała, nie ma żadnej bezcielesnej świadomości” "71. Świadomość, która - jak pisze Maurice Merleau-Ponty - „pro-

${ }^{66}$ M. M e r le a u - P o n ty, Oko i umyst. Szkice o malarstwie. Wybór, oprac., wstęp S. C ic how i c z. Przeł. E. B i eń k ow s k a [i in.]. Gdańsk 1996, s. 30.

${ }^{67}$ Zob. B e r l e a n t, Prze-myśleć estetykę.

${ }^{68}$ Ibidem, s. 120.

${ }^{69}$ Ibidem, s. 117.

${ }^{70}$ M. Me r le a u-P onty, Fenomenologia percepcji. Przeł. M. Kow alska, J. Migas iń s ki. Posł. J. M i g a s iń s ki. Warszawa 2001, s. 226.

${ }^{71} \mathrm{~B}$ e r l e a n t, Prze-myśleć estetykę, s. 110. 
jektuje się w świecie fizycznym i ma ciało [...]"72, zyskuje również wymiar somatyczny.

Słuszne zatem wydaje się, by w kontekście twórczości Kantora mówić i o doświadczeniu jako próbie własnych możliwości psychicznych i fizycznych, jako człowieka i artysty, i o doświadczeniu jako doznaniu siebie i dzieła jako organicznej niemal całości. Warto podkreślić, że w tak dosłownym ucieleśnieniu doświadczenie siebie i dzieła zyskuje nie tylko wymiar psychiczny, somatyczny, ale też estetyczny. Przy czym istotne jest, że - jak pisze John Dewey -

doświadczenie estetyczne nigdy nie jest wyłącznie estetyczne. Obejmuje bowiem cały zespół treści i znaczeń, które wprawdzie nie są estetyczne, lecz stają się takimi przez włączenie w ład rytmicznego dążenia do spełnienia. Materiał jako taki ma przede wszystkim charakter ludzki ${ }^{73}$.

W przypadku twórczości Kantora tym materiałem jest zarówno „ciało” tekstu, „ciało” dzieła, jak i, najdosłowniej, ciało samego artysty, które w nakreślonej perspektywie „staje się granicą i narzędziem transgresji rzeczywistości przetwarzanej w sztuce" 74 .

Utrata przytomności wyłącza świadomość, ale obezwładnia też ciało. Oba wymiary, somatyczny i psychiczny, łącząc się, warunkując wzajemnie, wpływają na kondycję ciała i umysłu. Wtedy właśnie, w stanie szczególnej ekstazy, poza wszelką kontrolą dokonuje się to niezwykłe zjednoczenie obrazu i jego twórcy, podmiotu i przedmiotu. Artysta utożsamia się z dziełem do tego stopnia, że traci świadomość siebie. Ten rodzaj doświadczenia można określić jako doświadczenie wewnętrzne w znaczeniu, jakie nadał mu Georges Bataille. Jawi się ono bowiem jako rodzaj transgresji między umysłem a ciałem. Za autorem Doświadczenia wewnętrznego przedstawione przez Kantora przeżycie ekstatyczne sztuki daje się opisać jako „podróż do kresu możliwości człowieka”75. Jak twierdzi Jay -

[Bataille] wiedział dobrze, że granicy doświadczenia dotyka się jedynie w śmierci, której nie da się włączyć w obręb życia, a która jest zarazem jego najbardziej intensywnym, ekstatycznym i głębokim momentem ${ }^{76}$.

Kantor własne dzieło sztuki sytuuje na granicy życia i śmierci. Jak pisze w wierszu $O$, Seigneur!, przełożonym z języka francuskiego przez Marię Rostworowską, pragnie „stworzyć:

\author{
w NIESKOŃCZONOŚCI \\ coś tak \\ DOKOŃCZONEGO \\ jak śmierć \\ Dzieło sztuki. [D 443]
}

W takim ujęciu sztuka jawi się jako akt metafizyczny.

${ }_{72}$ M e r l e a u - P o n ty, Fenomenologia percepcji, s. 156.

${ }^{73}$ D ew e y, op. cit., s. 400.

${ }_{74}$ M. Łu s z c zy ńs ka, Ciało jako granica - wypiski z Lévinasa. W zb.: Wizje i re-wizje, s. 475 .

${ }^{75}$ G. B a ta i 11 e, Doświadczenie wewnętrzne. Przeł. O. H e d e m a n n. Warszawa 1998, s. 58.

$76 \mathrm{~J}$ a y, op. cit., s. 527. 


\section{W stronę metafizyki}

Autor Umarłej klasy w sposób niezwykle emocjonalny i zmysłowy przeżywa swoją twórczość, angażuje się w nią bezgranicznie ${ }^{77}$, nawet zwyczajne codzienne czynności postrzega w kategoriach działań artystycznych:

Kiedy tworzę sztukę, mam wrażenie, że jest to jedyny sposób mojego życia. Oczywiście, muszę jeść, muszę pić kawę, muszę zażywać pewnych przyjemności życiowych, muszę jeździć taksówkami. Ale to jest prawie to samo co malowanie obrazu. [Interwencje, D 166]

Warto zaznaczyć, że - w myśl założeń autora - by tę ,niską” materię rzeczywistości uczynić sztuką, należy wprowadzić do niej fikcję, iluzję artystyczną, po prostu jakąś obcą siłę. Mają temu służyć praktyki, które określi twórca jako ,znachorskie”, „guślarskie”, „diabelskie”. Działania artystyczne przedstawią się zatem jako działania wyższego rzędu, jako metafizyczne. Jak sam napisze „o sobie w trzeciej osobie”: , Ta metafizyka fascynuje Kantora”78.

Akt tworzenia jawi się więc jako akt metafizyczny, tajemniczy, dokonujący się na granicy tego, co świadome i nieświadome, realne i wyobrażone, a nawet na granicy życia i śmierci. Kantor nieustannie podkreśla, że tworzyć - znaczy po prostu żyć, a zarazem wciąż odsyła do myślenia o śmierci. Sztuka przedstawia się zatem w jednym ujęciu jako manifestacja życia - jak wielokrotnie mawiał artysta - ale jest też nieustannym doświadczaniem , sił jakby »z tamtej strony « [...]" 79 . Ku granicy życia i śmierci prowadzi także pragnienie przekroczenia progu widzialności, o którym pisze twórca w Klasie szkolnej. Odsyła ono bowiem do zanegowania wizualności jako podstawowego warunku percepcji. Oglądaniu „od zewnątrz” przeciwstawiona zostaje chęć oglądania , od wewnątrz”, przesunięcie się z pozycji obserwatora, widza na pozycję uczestnictwa, zaangażowania, doświadczania samym sobą. Artysta tę sytuację tak podsumowuje:

\section{NIE JEST TO TAKIE ŁATWE. \\ CENĄ, KTÓRĄ SIĘ ZA TO PŁACI, JEST \\ SPOTKANIE ZE ŚMIERCIĄ. [Klasa szkolna, T 28]}

Sztuka jawi się więc jako działalność mistyczna, dokonująca się na granicy życia i śmierci. Jak podkreśla Kantor, ma ona dawać przeczucie istnienia tego d rug i e g o ś w i a t a ${ }^{80}$. Teatr według artysty jest miejscem, które odsłania tajne przejścia z „tamtej strony” do naszego życia., „Spektakl, zbliżony w swym charakterze do obrzędu i ceremonii, staje się operacją w s t r z ą s u. Nazywam go chętnie met a fizy czny m" 81 .

Metafizyczny wstrząs, o którym pisze twórca Teatru Śmierci, odsyła do Witkacowskiej koncepcji uczucia metafizycznego. I Witkacy, i Kantor myślą o odbior-

${ }^{77} \mathrm{P}$ i e n iąż e k (Akt twórczy jako mimesis, s. 84) odnotowuje m.in., że ,wielu naocznych świadków, a nawet członków zespołu Cricot 2 Kantor wielokrotnie wprawiał w zdumienie swoim niegasnącym zainteresowaniem dla kolejnego, załóżmy dwusetnego przedstawienia Umarłej klasy czy Wielopola, w którym uczestniczył z tym samym zaangażowaniem, co podczas premier czy prób".

T. K a n t o r, Mówić o sobie w trzeciej osobie. T 438.

${ }^{79} \mathrm{~K}$ a n t o r, Moja twórczość, moja podróż, M 15.

${ }^{80} \mathrm{~K}$ a n t o r, Lekcje mediolańskie, D 49.

${ }^{81} \mathrm{~K}$ a n t o r, Miejsce teatralne, T 387. 
cy swego dzieła, o emocjach, które dzieło powinno wzbudzać. Zgoła Witkacowsko brzmi wyznanie Kantora: „Dzieło sztuki musi posiadać dostateczny stopień obiektywizowania prywatnych przeżyć i doznań artysty" ${ }^{\prime 2}$. Te wewnętrzne przeżycia twórcy przefiltrowane przez dzieło powinny wpływać na odbiorcę, na jego emocje. Jak odnotowuje Jan Kłossowicz, w okresie wystawiania Umartej klasy:

szybko [Kantor] zwrócił uwagę na znaczenie reakcji emocjonalnych u widzów. Obok gry z iluzją i realnością za istotny czynnik uznał taki sposób kompozycji spektaklu, żeby świadomie wywoływać u odbiorców określone stany uczuciowe. Nazwał to ,architektoniką wzruszenia" $"$.

Witkacowskiemu uczuciu metafizycznemu odpowiadałoby zatem wzruszenie w twórczości artysty. „Nie zapominajmy o WZRUSZENIU” - zachęca autor Lekcji mediolańskich ${ }^{84}$. „Mnie najbardziej chodzi o efekty, które wywołują wzruszenie w świadomości widza" ${ }^{85}$.

Wydaje się zatem, że sztuka Kantora - niczym Czysta Forma Witkacego - ma transponować przeżycia, myśli, doznania artysty na odbiorcę, nawet za cenę uczynienia publicznym tego, co dla artysty najbardziej osobiste, indywidualne, a - jak pisze twórca Umartej klasy - „co dla »świata« wydaje się śmiesznością [...]”" Jakby na potwierdzenie tych słów w jednym z tekstów związanych ze spektaklem Nigdy tu już nie powrócę Kantor przyznaje -

\author{
Moje spektakle: \\ Umarta klasa, \\ Wielopole, Wielopole, \\ Niech sczezna artyści \\ $\mathrm{i}$ ten ostatni \\ Nigdy tu już nie powrócę- \\ wszystkie \\ są wyznaniami osobist ymi. [D 125]
}

Twórczość jest zatem najgłębszą ekspresją siebie. Życie i sztuka jawią się jako jedność. W działalności artystycznej Kantora życie zostaje utożsamione ze sztuką w sposób dosłowny:

...Malarstwo jest manifestacją życia

Pytanie: ,dlaczego maluję”, brzmi jak pytanie „dlaczego żyję” [Notatnik 1955... 1958... 1962, M 172]

Artysta przyznaje, że „Sztuka jest manifestacją życia. Najcenniejsze jest życie, coś, co ulatuje, przepływa" ${ }^{87}$.

Gdzie indziej powie:

Obraz staje się samą twórczością i manifestacją ży cia, jego przedłużeniem. [Abstrakcja umarła, niech żyje abstrakcja. O sztuce informel, M 169]

82 K a n t o r, Notatnik 1948... 1949... 1950..., M 109.

${ }^{83}$ J. Kło s s ow ic z, Kantor w Teatrze Pamięci. W zb.: Teatr Pamięci Tadeusza Kantora. Wypisy z przeszłości. Red. J. Chrobak, M. Wilk. Dębica 2008, s. 22.

${ }^{84} \mathrm{~K}$ a n t o r, Lekcje mediolańskie, D 71.

${ }^{85} \mathrm{~K}$ an tor, Interwencje, D 166.

${ }^{86} \mathrm{~K}$ a n t o r, Nigdy tu już nie powrócę, D 135.

87 T. Ka n t o r, Kryzys formy. M 483. 


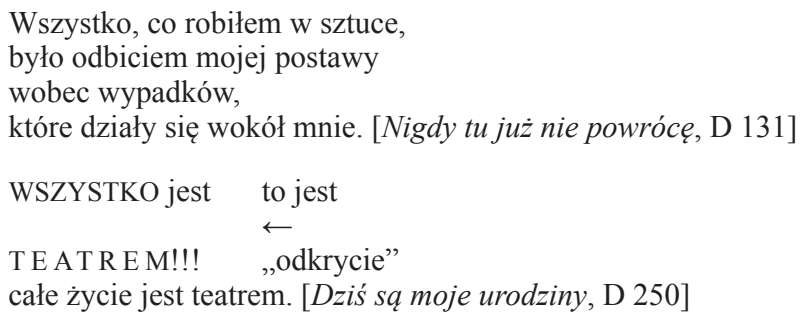

Można by dodać, że nie tylko życie jest teatrem, ale też teatr Kantora jest życiem i to nie jedynie w wymiarze metaforycznym, zważywszy na ilość czasu poświęcanego na przygotowania poszczególnych spektakli, liczbę prób, podróży i wystawien ${ }^{88}$.

„Tworzenie autentyczne to jest jednak przede wszystkim myślenie o sobie samym. O swojej sztuce" - powie artysta ${ }^{89}$. Dla Kantora zatem sztuka to najdosłowniej życie. W komentarzu do rewii Niech sczezna artyści napisze on:

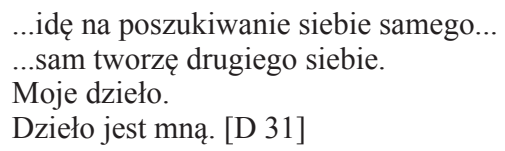

Powraca zatem motyw dosłownego utożsamienia się artysty z własnym dziełem. Jest to fakt wart podkreślenia, gdyż takiemu myśleniu o sobie i sztuce jako organicznej niemal całości przeciwstawić można Kantorowską refleksję o dziele jako bycie autonomicznym, niezależnym od twórcy. W rozmowie z Krzysztofem Miklaszewskim powie Kantor wprost: „Przyznam się Panu, że ja osobiście nie potrzebuję spektaklu po zrobieniu go, w momencie premiery kończy się moja twórczość" 90 . Warto wskazać tu na pewien paradoks: z jednej strony, dzieło jest autonomiczne, autor odcina się od niego, nie potrzebuje go, jak twierdzi, po stworzeniu, ale $-\mathrm{z}$ drugiej - to dzieło, spektakl teatralny, odwrotnie niż np. wiersz Różewicza, potrzebuje swego twórcy ${ }^{91}$. Teatr Kantora bez Kantora jest - o czym pisał Kott - ,jak ciało bez duszy" ${ }^{2}$. Zbigniew Raszewski, zwracając uwagę na liryczny charakter teatru autora Umartej klasy, podkreślał:

Kantor nie mówi nam o każdym z nas. Mówi o sobie, odwołując się do zdolności rozumienia drugiego człowieka, drzemiącej w każdym z nas.

${ }^{88}$ Wymowne w tym względzie przykłady stanowią Umarła klasa grana ponad 1100 razy i niewiele mniej grane Wielopole, Wielopole.

89 T. K a n t o r, Trafić do światowego muzeum. T 454.

${ }_{90}$ Miklas zewski, op. cit., s. 71.

${ }^{91}$ T. R ó ż e w i c z (,, Teatralizacja” poezji, poetów i... innych. W: Proza, s. 267) o niezależnym od twórcy bytowaniu dzieła pisze: „Chcę zwrócić uwagę, że wiersz żyje i może żyć bez swego autora, że nie ma potrzeby, aby wiersz jeździł ze swoim twórcą od miasta do miasta, od kraju do kraju w celach nie tylko artystycznych, ale reklamowych i zarobkowych... Oczywiście, autor może jeździć ze swoim utworem i autor wtedy jest jakby na utrzymaniu swojego wiersza... ale wiersz w istocie nie potrzebuje swojego twórcy. Autor może umrzeć, zwariować albo stać się »ulubieńcem publiczności«... utwór raz napisany, gotowy, żyje życiem własnym. Związki tego utworu ze spodniami lub krawatem autora są bez znaczenia... [...]". Ten humorystyczny komentarz trafnie przedstawia też myślenie Kantora w tym względzie, choć, oczywiście, przekonanie autora ambalaży o bycie dzieła niezależnym od artysty trudno odnieść do spektakli, które przecież nie są możliwe bez ich twórcy.

${ }^{92} \mathrm{~K}$ o t t, op. cit., s. 44. 
Nie dziw, że jest to przedstawienie ściśle zespolone z osobą Kantora. Takie miało być. Sama myśl, że mógłby to grać jakiś teatr gdzie indziej, bez Kantora, wydaje się groteskowa ${ }^{93}$.

Można powiedzieć, że teatr Kantora bez Kantora jest najdosłowniej Teatrem Niemożliwym.

Nawet perspektywa trafienia do światowego muzeum ${ }^{94}$ nie stanowi wyjścia z sytuacji, bo dzieło bez swego twórcy jest martwe.

Spuścizna autora spektaklu Wielopole, Wielopole jawi się jako nieustanne rekonstruowanie i reinterpretowanie jego dzieła, komentowanie i rewindykowanie idei artystycznych, ,zbieranie resztek" ${ }^{95}$, analizowanie minionych dokonań, podsumowywanie kolejnych etapów drogi twórczej, ale także jest ciągłym zaglądaniem w psychikę twórcy, rozpoznawaniem i reinterpretowaniem stanów wyobraźni, umysłu, jego własnej świadomości, a nawet stanów podświadomych. Sztuka to dla autora Umarłej klasy - mówiąc słowami Shustermana - twórczość i przeżycie, ukierunkowane działanie i otwarty odbiór jednocześnie, konstrukcja poddana kontroli, ale też zniewalające pochłonięcie ${ }^{96}$. Doświadczenie sztuki jawi się więc jako wynik interakcji między dziełem a jaźnią, dlatego jego charakter jest jednostkowy, niepowtarzalny ${ }^{97}$. Działalność artystyczna Kantora to forma ekspresji samego siebie w wymiarach duchowym i cielesnym. Stanowi, z jednej strony, ,zapis wewnętrzny", z drugiej - jawi się jako ucieleśnienie, dosłowne złączenie się artysty z dziełem. Sztuka okazuje się źródłem takiego doświadczenia, które, będąc mówieniem o sobie i świecie, jest zarazem szczególnym doznawaniem.

Zatem twórczość artysty, która nieodzownie wiąże się z wysiłkiem psychicznym i fizycznym, jest przede wszystkim doświadczaniem siebie (próbowaniem własnych możliwości) jako człowieka i artysty, ale i doświadczaniem (doznawaniem) własnego dzieła i własnej, psychicznej i fizycznej obecności w nim. Posługując się słowami Magdaleny Popiel, wolno stwierdzić, że doświadczenie estetyczne stanowi tutaj „klucz do przełamania klasycznych opozycji pomiędzy podmiotem i przedmiotem, a także pomiędzy sztuką a życiem" ${ }^{98}$. W dziele Kantora nie można tych obszarów oddzielić. Kantor jest twórcą, Kantorem-postacią na scenie życia i swojego teatru, a równocześnie widzem własnego dzieła, który jednak - mówiąc słowami Anny Krajewskiej - ,już nie ogląda, ale doświadcza (odbiera sztukę, ale doświadczenie estetyczne jest jego doświadczeniem fizykalnym, dosłownym)" 99 . W tej perspektywie doświadczanie estetyczne zyskuje wymiar dramatyczny.

Autor Umarłej klasy pokazuje najdosłowniej, że tworzyć sztukę znaczy tworzyć siebie; doświadczać siebie znaczy doświadczać własnego dzieła. Sztuka zatem jawi

${ }_{93}$ Z. R a s z e w s k i, Teatr w świecie widowisk. Dziewięćdziesiąt jeden listów o naturze teatru. Warszawa 1991, s. 177-178.

94 Zob. wypowiedź K a n t o r a Trafić do światowego muzeum (T).

95 T. K a n to r, 〈Zebrać resztki, które pozostały z przeszłości $\rangle$. D 402.

${ }^{96} \mathrm{~S}$ h u st e r m a n, Estetyka pragmatyczna [...], s. 99.

97 Zob. ibidem, s. 64-65.

${ }_{98}$ M. P o p i e 1, O nowa estetykę. Między filozofia sztuki a filozofia kultury. W zb.: Kulturowa teoria literatury. Główne pojęcia i problemy. Red. M. P. Markowski, R. Nycz. Kraków 2002, s. 352.

${ }_{99}$ A. K r a je w s k a, Dramatyczna teoria literatury. Zarys problematyki. Poznań 2009, s. 34 . 
się jako nieustanna podróż „w poszukiwaniu drugiego siebie” - jak mawiał artysta. Tworzyć znaczy ciągle przesuwać granice własnych możliwości fizycznych i psychicznych, balansować na granicy życia i śmierci, aż do jej przekroczenia. „Dalej już nic".

Abstract

IRENA GÓRSKA

(Adam Mickiewicz University in Poznań)

\section{EXPERIENCE AS A WORK'S TEST - A TEST OF ONESELF}

The article shows the activities of the artist in a perspective of broadly understood category of experience. The considerations raised here derive from Richard Shusterman's and Wolfgang Welsch's aesthetic thought, and are an attempt at reading Tadeusz Kantor's creativity in the optic of new aisthesis. Moreover, following Arnold Berleant, the category of "embodied subject" is introduced. All the aforementioned tropes direct the reflection on experience towards somatoaesthetics. This approach, used to refer to the creator himself as well as to his work showing the bodily dimension of the art and its sources, unfolds the mental conditions of the process of creation and Kantor's thinking of himself and of his creativity in terms of "infernum interior." Artistic creativity, indispensably linked to mental and physical effort, is not only seen as an experience of oneself and experience of one's own work, but also as a feeling of one's work and one's mental and physical presence in it. In this perspective the aesthetic experience earns a dramatic trait. 